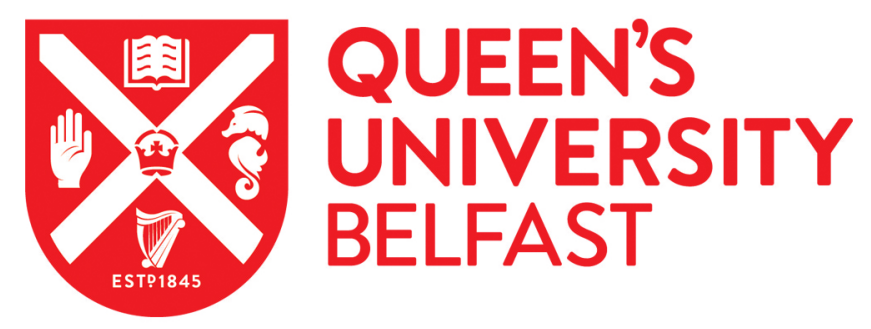

\title{
Religion, anti-slavery, and identity: Irish Presbyterians, the United States, and transatlantic evangelicalism, c. 1820-1914
}

Holmes, A. R. (2015). Religion, anti-slavery, and identity: Irish Presbyterians, the United States, and transatlantic evangelicalism, c. 1820-1914. Irish Historical Studies, 39(155), 378-398. https://doi.org/10.1017/ihs.2014.6

\section{Published in:}

Irish Historical Studies

\section{Document Version:}

Peer reviewed version

Queen's University Belfast - Research Portal:

Link to publication record in Queen's University Belfast Research Portal

Publisher rights

(c) Irish Historical Studies Publications Ltd 2015.

\section{General rights}

Copyright for the publications made accessible via the Queen's University Belfast Research Portal is retained by the author(s) and / or other copyright owners and it is a condition of accessing these publications that users recognise and abide by the legal requirements associated with these rights.

Take down policy

The Research Portal is Queen's institutional repository that provides access to Queen's research output. Every effort has been made to ensure that content in the Research Portal does not infringe any person's rights, or applicable UK laws. If you discover content in the Research Portal that you believe breaches copyright or violates any law, please contact openaccess@qub.ac.uk. 
Religion, anti-slavery, and identity: Irish Presbyterians, the United States, and transatlantic evangelicalism, c. 1820-1914

Abstract

Scholars have devoted much attention to the causes and consequences of Presbyterian emigration from Ulster to the thirteen colonies before 1776. This article moves beyond the eighteenth century to examine the continued religious links between Presbyterians in Ireland and the United States in the nineteenth century. It begins with an examination of the influence of evangelicalism on both sides of the Atlantic and how this promoted unity in denominational identity, missionary activity to convert Catholics, and revivalist religion during the first half of the century. Though Irish Presbyterians had great affection for their American co-religionists, they were not uncritical and significant tensions did develop over slavery. Irish Presbyterians were committed to the abolition of slavery, both temporal and spiritual. Their understanding of liberty seamlessly incorporated a desire to free Catholics from the spiritual slavery imposed by their church and to end chattel slavery in the United States. American Presbyterians eagerly supported the former, but the Irish commitment to the abolition of slavery in the United States led to tensions between the Presbyterian churches that was to last until the end of the Civil War. The article then examines the religious character of Scotch-Irish or Ulster-Scots identity in the late nineteenth century, which was articulated in response to the alleged demoralising influence of large-scale Irish immigration during and after the Famine of the 1840s, the socalled Romanisation of Catholicism, and the threat of Home Rule in Ireland. The importance of identity politics should not obscure religious developments, and the article ends with a consideration of the origins and character of fundamentalism, perhaps one of the most important cultural connections between protestants in Northern Ireland and the United States in the twentieth century.

Historians have devoted significant attention to the emigration of around 300,000 persons from Ulster to the New World in the eighteenth century. ${ }^{1}$ Most of these emigrants were Presbyterians who would have a considerable impact upon the religious, cultural, and political life of the thirteen colonies. In

\footnotetext{
${ }^{1}$ For example, Benjamin Bankhurst, Ulster Presbyterians and the Scots Irish diaspora, 1750-1764 (Basingstoke, 2014); H.T. Blethen and C.W. Wood, Jr, (eds), Ulster and North America: transatlantic perspectives on the Scotch-Irish (Tuscaloosa, Ala., 1997); R.J. Dickson, Ulster emigration to colonial America, 1718-1775 (London, 1966); Patrick Griffin, The people with no name: Ireland's Ulster Scots, America's Scots Irish, and the creation of a British Atlantic world, 1689-1764 (Princeton, 2001); M.A. Jones, 'The Scotch Irish in British America' in Bernard Bailyn and P.D. Morgan (eds.), Strangers within the realm: cultural margins of the first British Empire (Chapel Hill, NC, 1991), pp 284-313; K.A. Miller, Arnold Schrier, B.D. Boling, and D.N. Doyle, Irish immigrants in the land of Canaan: letters and memoirs from colonial and revolutionary America, 1675-1815 (Oxford, 2003).
} 
religious terms, the 'father' of American Presbyterianism was the Revd Francis Makemie from the Laggan area of north-west Ulster who established the first presbytery on American soil in 1706, and Gilbert and William Tennent from County Armagh were amongst the leaders of the Great Awakening. ${ }^{2}$ In political terms, many Presbyterian emigrants from Ulster were at the forefront of the revolutionary cause, which has been partly explained by their subordinate experience in the Irish confessional state that was dominated by the Church of Ireland and landlords belonging to that communion. Furthermore, most accounts of the relationship between Presbyterians in Ulster and North America end in 1776. For those who articulated a Scotch-Irish or Ulster-Scots identity at the turn of the twentieth century, the Revolution marked the end of an era in the history of both the United States and Ulster as the high ideals and hard-won prosperity of eighteenth-century protestant settlers were overshadowed by the influx of poverty-stricken Irish Catholics who by the 1830s comprised the majority of emigrants from Ireland. Even for academic authors in the twentieth century, the Revolution marked the point when these protestant settlers ceased to be a clearly defined ethnic group. In a social study of the Scotch-Irish published in 1962, the sociologist James G. Leyburn ended with the Revolution because 'the ScotchIrish were no longer a separate national stock but were Americans'. ${ }^{3}$

The relationship between Scots-Irish and American identities is one that has interested scholars, popular writers, and political interest groups on both sides of the Atlantic. Popular accounts describe the Scotch-Irish in heroic terms as an independent people who were religiously committed but also cantankerous, character traits that enabled them to overcome various trials and to contribute to the greatness of the United States. ${ }^{4}$ For professional historians, this narrative fails to convey the complexity of historical experience. A collection of essays edited by W.R. Hofstra on the Scots-Irish migration experience to 1830 notes that instead of a static and essentialist image, Scots-Irish identity was 'highly responsive to varied cultural and political contexts, themselves changing in time'. ${ }^{5}$ The

\footnotetext{
${ }^{2}$ B.S. Schlenther (ed.), The life and writings of Francis Makemie, father of American Presbyterianism (c.1658-1708) (Lewiston, ME, 1999); T.S. Kidd, The Great Awakening: the roots of evangelical
} Christianity in Colonial America (New Haven, 2007), passim; W.R. Ward, The protestant evangelical awakening (Cambridge, 1992), pp 265-73; M.J. Westerkamp, Triumph of the laity: Scots-Irish piety and the Great Awakening (New York, 1988).

${ }^{3}$ J. G. Leyburn, The Scotch-Irish: a social history (Chapel Hill, NC, 1962), p. vi.

${ }^{4}$ For example, Billy Kennedy, The making of America: how the Scots-Irish shaped a nation (Belfast, 2001) and Our most priceless heritage: the lasting legacy of the Scots-Irish in America (Belfast, 2005); K. F. McCarthy, The other Irish: the Scots-Irish rascals who made America (New York, 2011); J. H. Webb, Born fighting: how the Scots-Irish shaped America (New York, 2005).

${ }^{5}$ W. R. Hofstra, 'From the North of Ireland to North America: the Scots-Irish and the migration experience' in W.R. Hofstra (ed.), Ulster to America: the Scots-Irish migration experience, 1680-1830 (Knoxville, TN, 2012), p. xvi. See also D. N. Doyle, Scots Irish or Scotch Irish' in J. J. Lee and M. R. Casey (eds), Making the Irish American: history and heritage of the Irish in the United States (New York, 2007), pp 151-70, and M.P. Carroll, 'How the Irish became protestant in America' in Religion and American Culture, xvi (2006), pp 25-54. 
Scotch-Irish were adaptable and flexible, and one of the casualties of this process was Presbyterianism as many settlers, especially in the southern states, gradually joined Baptist and Methodist churches. Even the labels applied to this group have caused significant debate. The scholarly consensus is that the label 'Scotch-Irish' became widespread in the nineteenth century, though there is disagreement about the precise timing - some argue it was a direct response to Irish Catholic immigration during and after the Famine while others argue it was used earlier in the century by economically better-off immigrants who opposed Irish radical politics and Jeffersonian democracy. ${ }^{6}$

This article moves beyond the focus on the eighteenth century to uncover and examine the continued links between Presbyterians in Ireland and the United States in the nineteenth century, a topic that has received little scholarly attention. ${ }^{7}$ The emphasis is on religious connections, and especially the relationship between Presbyterians associated with the General Assembly of the Presbyterian Church in Ireland and the Presbyterian Church of the United States of America, particularly the Old School General Assembly after 1837. It describes the important role that Irish Presbyterian immigrants in the nineteenth century played in forging and maintaining transatlantic connections, a shared commitment to missionary activism and anti-Catholicism, and the religious source of Scotch-Irish identity from the 1830s. From the beginning of this period, Presbyterians in both countries believed that their brand of religion brought temporal benefits and produced individuals with the evangelical and bourgeois values of hard-work, temperance, moral probity, and religious commitment. Much has been written about the importance of the evangelical networks that crisscrossed the Atlantic throughout this period, but the contribution of Irish Presbyterian evangelicals has not been highlighted. ${ }^{8}$ As demonstrated below, they played an active - often proactive - role in the formation and maintenance of these networks and shared the optimistic millennial vision that underpinned evangelical unity and activity. The irony is that by doing so they undermined a distinctive Presbyterian identity in the twentieth century by promoting an emphasis on personal conversion that eroded denominational loyalty.

These themes are explored in three sections. The first examines the impact of the growth of evangelicalism on Presbyterians on both sides of the Atlantic and how this promoted unity in

\footnotetext{
${ }^{6}$ For an earlier date see, Peter Gilmore and K. A. Miller, 'Searching for "Irish” freedom - settling for “Scotch-Irish” respectability: southwestern Pennsylvania, 1780-1810’ in Hofstra, Ulster to America, pp 165-210.

${ }^{7}$ Important exceptions include: S. J. Brown, 'Presbyterian communities, transatlantic visions and the Ulster revival of 1859' in J. P. Mackey (ed.), The cultures of Europe: the Irish contribution (Belfast, 1994), pp 87-108; D.N. Livingstone and R.A. Wells, Ulster-American religion: episodes in the history of a cultural connection (Notre Dame, 1999); D. W. Miller, 'Ulster evangelicalism and American culture wars' in Radharc: A Journal of Irish and Irish-American Studies, v-vii (2004-6), pp 197-215.

${ }^{8}$ The best introduction to the transatlantic character of nineteenth-century evangelicalism is, John Wolffe, The expansion of evangelicalism: the age of Wilberforce, More, Chalmers, and Finney (Nottingham, 2006) and D.W. Bebbington, The dominance of evangelicalism: the age of Spurgeon and Moody (Leicester, 2005).
} 
denominational identity, missionary activity to convert Catholics, and revivalist religion between 1830 and 1860. The evidence presented in this section reflects the positive view Irish Presbyterians had of their American co-religionists, but they were not uncritical and significant tensions did develop over slavery. Irish Presbyterians were committed to the abolition of slavery, both temporal and spiritual. Their understanding of liberty seamlessly incorporated a desire to free Catholics from the spiritual slavery imposed by their church and to end chattel slavery in the United States. American Presbyterians eagerly supported the former, but, as section two demonstrates, the Irish Assembly's robust support for the abolition of slavery in the United States led to tensions between the Presbyterian churches that was to last until the end of the Civil War. The final section discusses how the themes outlined in the first section were revived after 1866 and were used to assemble a religiously-informed Scotch-Irish or Ulster-Scots identity. This identity was articulated in response to the alleged demoralising influence of large-scale Irish immigration during and after the Famine of the 1840s, the so-called Romanisation of Catholicism, and the threat of Home Rule in Ireland. The importance of identity politics should not obscure religious developments, and the article ends with a consideration of the origins and character of fundamentalism, perhaps one of the most important cultural connections between protestants in Northern Ireland and the United States in the twentieth century.

I.

Evangelicalism was a movement of religious renewal amongst protestants that emerged in the early eighteenth century and is most associated with the rise of Methodism and religious revivals amongst Calvinists in America and Scotland. ${ }^{9}$ By the end of the century, its emphasis on personal conversion and missionary zeal, which relaxed denominational barriers between protestants, seemed to meet the needs of societies convulsed by conflict and economic change. The dislocation of the period led to the unprecedented growth of evangelicalism and provided the basis for co-operation in revivalism and missionary activity between North America and the United Kingdom. ${ }^{10}$ It also transformed Presbyterianism in Ireland and, from the 1820s onwards, evangelicalism became the driving force within the Synod of Ulster, the largest Presbyterian grouping on the island at the time. ${ }^{11}$ The growing influence of evangelicalism was demonstrated in 1829 when a small number of Arian ministers who denied the doctrine of the Trinity were forced to leave the Synod. This led in 1840 to the formation of

\footnotetext{
${ }^{9}$ M.A. Noll, The rise of evangelicalism: the age of Edwards, Whitefield and the Wesleys (Leicester, 2004).

${ }^{10}$ M. A. Noll, 'Revolution and the rise of evangelical social influence in North Atlantic societies', in M. A. Noll, D. W. Bebbington, and G. A. Rawlyk (eds), Evangelicalism: comparative studies of popular protestantism in North America, the British Isles, and beyond, 1700-1990 (Oxford, 1994), pp 113-36.

${ }^{11}$ R. F. G. Holmes, 'The triumph of evangelicalism in the Synod of Ulster in the early nineteenth century', in W. D. Patton (ed.), Ebb and flow: essays in church history in honour of R. Finlay G. Holmes (Belfast, 2002), pp 9-19; A. R. Holmes, The shaping of Ulster Presbyterian belief and practice 1770-1840 (Oxford, 2006).
} 
the General Assembly of the Presbyterian Church in Ireland, a product of the union of the Synod and the Secession Synod, which had been the growth sector of Presbyterianism between 1750 and 1820 . During this process of reform, Presbyterian evangelicals looked to both Scottish and American Presbyterians for support and models to imitate, and the Synod of Ulster in the early 1830s joined in correspondence with orthodox protestant churches in Europe and America. Communication was initiated by the General Assembly of the Presbyterian Church in the United States, and their letter of 1830 commented favourably on the outcome of the Arian controversy, the continuing personal correspondence between individual Presbyterians across the Atlantic, and the prosperity of the American church. ${ }^{12}$ The Synod were fulsome in their support for renewed correspondence and hoped that it would signal the emergence of a trans-national Presbyterian community. 'From the present state of the Parent Churches in Scotland, and from the number, the harmony, and order of your churches, so widely spread over your vast continent, we learn the excellence of our form of church government, and its tendency to promote spiritual edification - restrain vice - advance holiness, and preserve the spirit of unity in the bond of peace.' They gave thanks to God for the symptoms of revival across the Presbyterian world and hoped that God 'will continue to bless us, and will soon enable us to take a place among the Presbyterian churches in the world, as one holding fast the truth, and walking in the beauty of holiness'. ${ }^{13}$ The American church agreed that union was necessary as the 'signs of the times admonish us that there are labours to be performed, and triumphs to be achieved, which demand the harmonious and concentrated moral powers of the church'. These tasks included missionary activity, Bible and tract distribution, the extension of Sunday schools, and the promotion of temperance. ${ }^{14}$

Religious revival and missionary activity were closely associated in Presbyterian minds as both were means of bringing about the millennial reign of Christ through the conversion of the world. Writers on both sides of the Atlantic interpreted revival as either a preparation to or an inauguration of the Millennium predicted in Revelation 20. ${ }^{15}$ Between 1824 and 1835, revivals under the leadership of Charles Finney had affected the north-eastern United States and these had provoked significant interest amongst Irish Presbyterians who longed for a similar awakening. ${ }^{16}$ However, in 1837 the General Assembly of the Presbyterian Church in the United States of America divided in part over the means of promoting revival, as well as differences over theology and attitudes to slavery. ${ }^{17}$ The so-called 'new measures’ revivalism of Finney and New School Presbyterians was opposed by the Old School

\footnotetext{
${ }^{12}$ Minutes of a General Synod, held at Coleraine, 1831 (Belfast, 1831), pp 39-40.

${ }^{13}$ Minutes of a General Synod, held at Monaghan, 1832 (Belfast, 1832), pp 40, 41.

14 ‘Presbyterian Church, America’ in Orthodox Presbyterian, iii (Aug., 1832), p. 379.

${ }^{15}$ A. R. Holmes, 'The uses and interpretation of prophecy in Irish Presbyterianism, 1850-1930' in

Crawford Gribben and A. R. Holmes (eds), Protestant millennialism, evangelicalism, and Irish society, 1790-2005 (Palgrave, 2006), pp 156-9; J. H. Morehead, ‘Apocalypticism in mainstream protestantism, 1800 to the present' in B. J. McGinn, J. J. Collins, and S. J. Stein (eds), The Continuum history of apocalypticism (New York, 2003), pp 468-9.

${ }^{16}$ Wolffe, Expansion of evangelicalism, pp 69-76.

${ }^{17}$ B.J. Longfield, Presbyterians and American culture: a history (Louisville, KY, 2013), pp 91-6.
} 
majority. Irish Presbyterians shared the concerns of the Old School about the emotionalism of Finney's brand of revivalism, but they continued to desire a religious revival. ${ }^{18}$ In 1843 the Irish General Assembly rejoiced that Old School Presbyterians had avoided the 'folly and extravagance' of certain forms of revivalism and linked genuine revival to the dawning of the Millennium: 'We hail the blessings you announce as the indications of the dawn of the glory of the latter days; and when we see the arm of the Lord revealed in these effusions of His Spirit, we are taught that, when the set time is come, all the ends of the earth will be very speedily evangelised.' 19

One of the symptoms of the progress of the gospel would be the collapse of the age-old enemy, Catholicism. It is important to underline that anti-Catholicism was a prominent component of transatlantic Protestantism during this period and that it was sometimes even more virulent in protestant-dominated areas such as Scotland and the United States than it was in Ireland. ${ }^{20}$ In that context, the conversion of Catholics in Ireland through missionary activity was seen as a principal means of combating popery on both sides of the Atlantic. This shared campaign was heightened by the Great Famine, which was viewed by Presbyterians as a God-given opportunity to achieve the conversion of the Irish Catholic diaspora. At the centre of this effort was John Edgar, professor of theology for the Presbyterian Church in Ireland and enthusiastic advocate of philanthropic and missionary causes. Edgar made a heartfelt plea for practical assistance to starving Irish Catholics in late 1846, collected around £20,000 for famine relief, and set-up the Belfast Ladies’ Relief Association for Connaught to maintain industrial schools in the west. ${ }^{21}$ In May 1847 Edgar issued an appeal to evangelicals in the United States to support Presbyterian mission in Ireland. The 'terrible scourge' of the Famine provided the opportunity 'to break the chain by which the Romish priest so long led his devotee captive, and to set the prisoner free'. The address discussed the long-standing family connections between Ireland and the United States, but also focused on the contemporary threat of Catholic emigration to America. 'What Romanism is even America is beginning to learn', and Edgar pointed as evidence to the difference between 'the Northern Scotch-Irish emigrant, and the Southern Roman-Irish emigrant'. ${ }^{22}$

\footnotetext{
${ }^{18}$ A. R. Holmes, 'The experience and understanding of religious revival in Ulster Presbyterianism, c. 1800 to 1930 ' in Irish Historical Studies xxxiv (2005), pp 368-70.

${ }^{19}$ Minutes of the General Assembly of the Presbyterian Church in Ireland [hereafter MGA], i (1843), p. 347.

${ }^{20}$ John Wolffe, 'Anti-Catholicism and evangelical identity in Britain and the United States, 1830-1860' in Noll et al, Evangelicalism, pp 179-97; Katie Oxx, The nativist movement in America: religious conflict in the nineteenth century (London, 2013).

${ }^{21}$ D. W. Miller, 'Irish Presbyterians and the great famine’ in Jacqueline Hill and Colm Lennon (eds), Luxury and austerity (Historical Studies, xxi, Dublin, 1999), pp 169-73, and 'Edgar, John (17981866)' in Oxford Dictionary of National Biography (Oxford, 2004).

${ }^{22}$ An appeal on behalf of the Home Mission of the General Assembly of the Presbyterian Church in Ireland, respectfully addressed to their Christian brethren of all evangelical denominations in America ([Belfast, 1847]), 2.
} 
Deputations from Ireland were dispatched to the United States to gather support - two were sent directly on behalf of the mission to Irish Catholics in 1848 and 1859, and two more from the General Assembly in 1858 and 1867. The deputation of 1848 consisted of the Revds E.M. Dill and Jonathan Simpson whose travels amongst various Presbyterian bodies in the northern states yielded contributions of over $\$ 25,000 .^{23}$ The credentials that Edgar provided for the deputation stated clearly the belief that 'the conversion of Irish Romanists is a matter of deep interest to the whole Christian world, and especially to the New World, injured and oppressed by their immigration'. Every effort ought to be made to maintain missions to Catholics and so Dill and Simpson had been deputed 'to visit the United States for the purpose of awakening sympathy on behalf of Irish Roman Catholics in their present remarkable condition, and obtaining aid for missions to them'. ${ }^{24}$ An important outcome of this first deputation was the contact made between the Irish church and George Hay Stuart, a Presbyterian immigrant who left Ireland in 1831 and had established himself as a successful merchant in Philadelphia. ${ }^{25}$ Stuart became an elder in the First Reformed Presbyterian Church in that city and gained national prominence in his connection with the YMCA and his chairmanship of the United States Christian Commission during the Civil War, which led to political influence through a longlasting friendship with Ulysses S. Grant. His facilitation of the deputation in 1848 led to Stuart being regarded 'as a sort of representative of the Irish Presbyterian Church before the Presbyterians of America' ${ }^{26}$ He was heavily involved in organising the 1859 deputation from Ireland, which comprised Edgar, S.M. Dill, and David Wilson, and which collected £6,000 in donations. ${ }^{27}$

It is clear that a number of prominent American Presbyterians such as Stuart were keen to encourage the conversion of Catholic Ireland as a means of resisting the challenge of 'popery' in their own state. Another was the minister of Elizabethstown, New Jersey, Nicholas Murray, a Catholic immigrant from Ireland who converted to Presbyterianism and gained notoriety for a series of controversial letters to John Hughes, Catholic archbishop of New York, written under his pen name, 'Kirwan'. ${ }^{28}$ Significantly, John Edgar republished Murray’s letters in Belfast in the early 1850s. ${ }^{29}$

\footnotetext{
23 'Abstract Report of the Deputation to America, on behalf of the Home Mission - July, 1849', Missionary Herald of the General Assembly of the Presbyterian Church in Ireland [hereafter Missionary Herald] (Aug. 1849), pp 694-5.

${ }^{24}$ Jonathan Simpson, Annals of my life, labours, and travels (Belfast, 1895), p. 304.

${ }^{25}$ Dictionary of American religious biography (2nd edn, Westport, CN, 1993), pp 528-9.

${ }^{26}$ The life of George H. Stuart, written by himself, ed. R. E. Thompson (Philadelphia, 1890), p. 67.

27 'Roman Catholic Mission. The late deputation to the United States' in Missionary Herald (Feb. 1860), pp 484-5, and 'The late deputation to the United States' in Missionary Herald (Apr. 1860), pp 524-5.

${ }^{28}$ R.A. Billington, The protestant crusade 1800-1860: a study of the origins of American Nativism (New York, 1938), pp 253-5.

${ }^{29}$ Homely truth for honest men. Letters to the Right Reverend John Hughes, Roman Catholic Bishop of New York. By Kirwan. With an introductory essay by John Edgar, D.D., and notes by Samuel O.

Edgar, D.D. (Belfast, 1850); Letters to the Right Reverend John Hughes, Roman Catholic Bishop of
} 
Murray visited Ireland in 1853 and gave a very positive description of the work of Edgar's industrial schools, which he claimed were extending morals, religion, and industry in the face of Catholic priests who had 'made Ireland a godless, Christless land'. He believed that 'the only cure for Ireland is that which these schools is applying, to instruct and to evangelize the people. When the knowledge of the Bible and of Jesus Christ supplants the wretched idolatry of Popery, the days of Ireland's mourning are ended. ${ }^{30}$ Murray was hopeful that this process was well in hand with the extension of education, the growing sense of missionary responsibility on the part of protestant churches in Ireland, and the arrival of Scottish and English farmers to Ireland in the wake of the Famine. Murray and Stuart together visited Ireland in 1860 to determine the religious condition of the country. ${ }^{31}$ They visited the Presbytery of Athlone and, according to Stuart, 'had an excellent opportunity of contrasting the influence of the Gospel of Christ in improving the temporal condition of the people, with the effects of popery, manifest in the filth, poverty, ignorance, and vice of the unevangelized districts' ${ }^{32}$

Murray and Stuart also visited Ireland to see the progress and results of the 1859 revival, a spectacular outburst of religious fervour in protestant-dominated areas of Ulster. ${ }^{33}$ When the 'businessmen's revival' broke out in New York in 1857, it seemed that the millennial hopes of Presbyterians were to be realised. The General Assembly dispatched a delegation to North America, and the published account of that visit by one of the delegates, William Gibson, professor of Christian ethics in the Presbyterian College, Belfast, noted favourably 'the noiseless character of the work, and the absence of all unnatural excitement'. ${ }^{34}$ Gibson's description of an intense yet restrained revival matched the type Irish Presbyterians desired, yet the Ulster revival of 1859 unleashed forces that challenged the status quo and caused controversy. In particular, the various physical manifestations that accompanied a minority of conversions became the most infamous characteristic of the revival. These had not been a feature of the 1857/8 revival, but for the principal evangelical critic of the Ulster revival, Isaac Nelson, this behaviour defined revival and was the natural outcome of bad American religion. He claimed, 'To America must we look as the rock from [which] the Revivalism has been hewn; and the more intimately we comprehend American religion the more thoroughly will we be convinced that Revivalism is a sham. America is the Brobdignag of the earth, everything there is on a grand scale, even dishonesty. America is the land of Mormonism, Table-turning, Spirit-rapping, dept-

New York. With an introduction by John Edgar, D.D., and notes by the late S.O. Edgar, D.D. (Belfast, 1851).

${ }^{30}$ [Nicholas Murray], Men and things as I saw them in Europe. By Kirwan (New York, 1853), pp 253-

4.

${ }^{31}$ Life of Stuart, pp 120-6.

${ }^{32}$ S. I. Prime, Memoirs of the Rev. Nicholas Murray, D.D. (Kirwan) (New York, 1863), pp 331-2.

${ }^{33}$ A. R. Holmes, 'The Ulster revival of 1859: causes, controversies and consequences' in Journal of Ecclesiastical History, lxiii (2012), pp 488-515.

${ }^{34}$ Pentecost: or, the work of God in Philadelphia, A.D. 1858. Prepared by the Young Men's Christian Association. With an introductory statement by the Rev. William Gibson (Belfast, 1859), p. ix. 
repudiation, Slavery, and Revivals.' 35 Nelson did not represent the views of most Ulster evangelicals who supported the sober-minded analysis offered by James McCosh, the Scottish professor of logic and metaphysics at Queen's College, Belfast. At the annual meeting of the Evangelical Alliance in Belfast in September 1859, McCosh argued that the bizarre behaviour of the revival could be explained as a physiological response to the intensity of emotion, the temperament of the individual, and the emotional character of the Irish, and 'that no bodily state is an evidence of an operation of the Spirit of God'. ${ }^{36}$ McCosh articulated the consensus amongst the clergy that it was the conduct of the converts that would verify their conversions.

II.

Despite the unity achieved through a shared commitment to revival, mission, and opposition to Catholicism, the comments of Nelson demonstrate that the issue of chattel slavery caused significant tension amongst Presbyterian evangelicals. As with most protestants outside the United States, Irish Presbyterians desired the abolition of slavery, though there was disagreement over the precise course of action to follow and their attitude to the policy of the northern states. ${ }^{37}$ Nelson was particularly outspoken, and was a notable advocate of the 'Send Back the Money' campaign in 1844 against the Free Church of Scotland who were urged by abolitionists to return donations received from the southern states unless slavery was abolished. ${ }^{38}$ Furthermore, Nelson's forthright commitment to the exclusion of slaveholders from membership of the Evangelical Alliance at its inaugural meeting in August 1846 caused an almost fatal split in the organisation. ${ }^{39}$ Like Nelson, most Presbyterian ministers and a significant proportion of the laity in mid-Victorian Ireland were political liberals. Their support for social and political reform reflected their continued opposition to Church of Ireland ascendancy, the inspiration provided by their seventeenth-century forefathers, and the crusading character of evangelicalism. ${ }^{40}$ They believed that one of the temporal blessings the expansion of

\footnotetext{
${ }^{35}$ Isaac Nelson, The year of delusion: a review of 'The Year of Grace' (Belfast 1862), p. 76.

${ }^{36}$ James McCosh, The Ulster revival and its physiological accidents. A paper read before the Evangelical Alliance, September 22, 1859 (Belfast, 1859), p. 10.
}

${ }^{37}$ For an overview of the theological responses of foreign protestants see, M. A. Noll, The Civil War as a theological crisis (Chapel Hill, NC, 2006), pp 95-123.

${ }^{38}$ Alasdair Pettinger, 'Send back the money: Douglass and the Free Church of Scotland' in A.J. Rice and Martin Crawford (eds), Liberating sojourn: Frederick Douglass and transatlantic reform (Athens, GA, 1999), pp 31-55; Daniel Ritchie, 'Antislavery orthodoxy: Isaac Nelson and the Free Church of Scotland, c. 1843-1865' in Scottish Historical Review (forthcoming).

${ }^{39}$ Daniel Ritchie, 'Abolitionism and evangelicalism: Isaac Nelson, the Evangelical Alliance, and the transatlantic debate over Christian fellowship with slaveholders’ in Historical Journal, lvii (2014), pp 421-46.

${ }^{40}$ R. F. G. Holmes, Henry Cooke (Belfast, 1981), pp 150-86; A. R. Holmes, 'Covenanter politics: evangelicalism, political liberalism, and Ulster Presbyterians, 1798 to 1914' in English Historical 
evangelicalism would bring would be the abolition of slavery in the United States. In response to a memorial from the Belfast Anti-Slavery Society, the Irish General Assembly in 1843 unanimously passed a resolution that they considered 'the enslavement of our fellow-creatures subversive of the natural rights of man, opposed to the spirit and precepts of the Gospel, and ruinous to the temporal and eternal interests of multitudes of the human race'. The resolution noted the 'oppressive system of slavery' that existed in America, 'and particularly in many parts of the United States, where the knowledge of Christianity might have been expected to destroy so great an evil'. As a consequence, they resolved to use their influence with American Presbyterians to 'earnestly recommend their taking such practical steps as may tend to abolish an evil of such awful magnitude'. ${ }^{41}$ During the debate around the resolution, the contradiction between the religious freedom and vitality expressed through revivals and the continued existence of slavery in the United States was noted. The Revd John Johnston of Tullylish exclaimed, 'American revivals have been spoken of, and many of us have been delighted to hear and read of them; but what a cloud is thrown over the sunshine of revivals, when Christian Churches, and even ministers, are involved in an abomination so repugnant to the spirit and precepts of Christianity!' The minister of Larne congregation, the Revd H.W. Molyneux, suggested that money sent from America to support mission in Ireland should be returned unless slavery was abolished, while the Revd D.G. Brown of Newtownhamilton wanted no communion with the Old School Assembly so long as they countenanced slavery. ${ }^{42}$ The resolution was transmitted to the Old School Assembly along with a letter that recognised the difficulty of abolishing a system that 'has been so long incorporated with the very framework of your civil institutions'. Yet the Irish Assembly felt 'assured that, by continuing to bear against it your earnest and consistent testimony, you will eventually succeed in achieving its abolition' and hoped that the American church would 'not rest until the oppressed are permitted to go free'. ${ }^{43}$

The Old School Assembly was in an awkward position as a third of its members were in the southern states, and in 1845 they passed a resolution that slavery was taught in the Bible and that slaveholders ought to treat their slaves with humanity. ${ }^{44}$ The American response to the Irish resolution noted that they did not wish 'either to repel the counsel of brethren abroad, or evade responsibility and discussion, on this momentous question, at home’. They presumed that Irish Presbyterians were 'strangers ... to the principal cause of the aggravations which attend domestic slavery in this country', namely the attitude of the South and the actions of extreme abolitionists. ${ }^{45}$ The letter was discussed at length by the Irish Assembly in 1846 and their response noted the commitment of both churches to

Review, cxxv (2010), pp 340-68; G. R. Hall, Ulster liberalism, 1778-1876: the middle path (Dublin, 2011).

${ }^{41}$ MGA, i (1843), p. 235.

42 The debate was reported in detail in the Banner of Ulster, 14 July 1843.

${ }^{43}$ MGA, i (1843), pp 347-8.

${ }^{44}$ P. J. Wallace, ““The bond of union”: the Old School Presbyterian Church and the American nation, 1837-61' (3 vols, unpublished PhD thesis, University of Notre Dame, 2004), ii, 423-32.

${ }^{45}$ MGA, i (1846), p. 508. 
liberty and the golden rule (do to others as you would have them do to you). If that was so, why then did the American Assembly uphold slavery and the treatment of human beings as property? Surely these principles bound them to call for immediate abolition? Regardless of the law, 'no Christian ought to hold in forcible servitude any one of whom he has obtained possession, directly or indirectly, by the crime of man-stealing'; no church member ought to withhold religious instruction from any individual and that families of slaves should not be forcibly separated; 'and we conceive that no Church should hold communion with those who are guilty of such violations, alike of the laws of nature and revelation'. The Irish Assembly observed with regret that their co-religionists' condemnation of the errors of abolitionists was stronger than for 'those who are seeking to perpetuate the accursed system of American bondage'. Furthermore, 'We greatly apprehend that your defence of slavery or servitude, in the abstract, accompanied by your feeble reprehension of its admitted enormities, is much more likely to retard its abolition, or mitigation, than any amount of violence or imprudence on the part of those who seek its removal., 46

Such a strongly-worded declaration was bound to draw a response, and it was signed by Charles Hodge, moderator of the Old School Assembly in 1846. The letter began defensively and became increasingly belligerent. It queried the introduction of the issue of slavery to their correspondence on the basis that the church's mission was 'to give the blessed Gospel, and not free Institutions, to the human race'. Nevertheless, the American Assembly felt that they needed to make a definite statement of their position owing, in part, to 'the obviously erroneous opinions you have formed both of it and our relations to it'. The civil aspect of the question did not concern the church, but the moral aspect did, and this allowed them to challenge the failure of Irish Presbyterians to convert Irish Catholics. 'That we have done all we could, much less, all we should have done, we will no more venture to assert, than we suppose you would contend that you had fully discharged your duties, during the last two centuries, to the millions of Popish idolaters who dwell around you.' Non-Americans could not possibly comprehend the complex issues involved in the system of slavery and the letter rejected the idea of excluding slaveholders from Christian communion. 'We have, of course, no idea of discussing at large a question of this sort with you, much less of defending, in a brief letter to you, our conduct or our faith, our Church or our country, against the calumnies of ignorant and corrupt men, either in your county or ours. ${ }^{47}$ A special committee of the Irish General Assembly appointed to respond to the letter were of the opinion that it was 'unworthy of an answer', but they had, nevertheless, decided to do so. Professor Robert Wilson read their response to the Assembly in July 1847 and those parts about slavery 'were received with deafening cheers'. ${ }^{48}$ The Irish church readily received criticism about their failure to convert Irish Catholics from their spiritual slavery but were not to be moved on the principal issue: 'Slavery, root and branch, was hated with a perfect hatred, as it existed in our own West India Islands, and our opposition only ceased with the death of slavery there;

\footnotetext{
${ }^{46}$ MGA, i (1846), pp 510-11.

${ }^{47}$ MGA, i (1847), pp 622-3.

${ }^{48}$ Banner of Ulster, 16 July 1847.
} 
nor can we view it with greater complacency as it converts free America into a foul misnomer, and forms a dark and deadly stain on the escutcheon of evangelical Presbyterianism. ${ }^{49}$

Owing to the fallout from this exchange and the on-going Famine in Ireland, the correspondence between the two churches before the Civil War focused on mission and revival and downplayed slavery. ${ }^{50}$ The Irish Assembly did engage in correspondence with other Presbyterian bodies in America who were more decided in their opposition to slavery, including the Free Presbyterian Church of the United States and the various bodies of Associate Reformed Presbyterians that formed the United Presbyterian Church of North America in May 1858. ${ }^{51}$ When the Civil War eventually broke out in April 1861, most Presbyterians in Ireland believed that slavery was the cause of the conflict and there was qualified support for the Northern cause. The recently-founded Evangelical Witness and Presbyterian Review supported the Union cause, combined 'thorough abolitionism' with 'strong doctrinal orthodoxy', and 'whose attention to the faults of the United States did not make it waver in its support of antislavery Americans'. ${ }^{2}$ For one of the contributors, William Gibson, the political issue may have been about the constitution, but the war was about slavery. ${ }^{53}$ Gibson was critical of the support offered by the London Times for the southern states but was also keen to show that Irish Presbyterians were not slavishly following the policy of the North. Nevertheless, 'this is in reality an anti-slavery war' and he hoped that the 'fiery trial' would continue until it had 'burned up the corruptions of the State, and fused all interests into a nationality - great, pure, and free'. ${ }^{54}$ In April 1863, S.M. Dill, a member of the delegation to America in 1859, lamented the tragedy of the civil war that pitted against each other evangelicals from the North and South, yet it was clear to him which side was in the right.

Southern independence, indeed! Yes; an independence of the Abolitionist North that the Southern planter may be free to rivet more closely the fetters of the slave. Independence! yes, that she may shut herself in from the annoying gaze of the world, and render herself independent of the opinion of mankind. Independence! yes, that she may be enabled to traffic in human flesh, and human souls too - aye, the truth must be spoken - that she may sell her

\footnotetext{
${ }^{49}$ MGA, i (1847), p. 625.

${ }^{50}$ MGA, i (1848), pp 866-7; ii (1850), pp 59-60; (1853), pp 216-17; (1854), pp 304-5.

${ }^{51}$ For the Free Presbyterian Church, see, MGA, i (1848), pp 702-6; ii (1855), pp 386-7. For the Associate Reformed Presbyterians, see, MGA, i (1848), pp 700-2; ii (1852), pp 133-4, 135-6; (1853), pp 217-20; (1854), pp 301-4; (1855), pp 390-4; (1856), pp 478-81. J.R. McKivigan, The war against proslavery religion: abolitionism and the Northern churches, 1830-65 (New York, 1984), pp 28-9, 101-5, 163.

52 Noll, Civil war, p. 104.

${ }^{53}$ William Gibson, 'The trans-Atlantic struggle' in Evangelical Witness and Presbyterian Review, i (1862), pp 17-18.

${ }^{54}$ William Gibson, 'The American Civil War and Slavery' in Evangelical Witness and Presbyterian Review, i (1862), pp 138, 139.
} 
own children. Independence of Northern tariffs. Independence! yes, an independence of humanity, of conscience, and of God! 55

Some Irish Presbyterians, including Isaac Nelson, were openly critical of the hypocrisy shown by northern evangelicals, especially Charles Hodge, who had not done enough to end slavery before the war. ${ }^{56}$ The Revd G.H. Shanks, a childhood friend of G.H. Stuart who was himself a life-long abolitionist, noted that Hodge 'has declared himself an opponent of the system which he formerly argued, with all his Jesuitical dialectics, to have never been disapproved by Christ or his apostles'. ${ }^{57}$ For Shanks, Hodge was the 'Prince of Slavery apologists' who by 'force of intellect and theology' was an abolitionist, 'yet he ... lays to rest the conscience of a slaveholder, by assuring him that slaveholding is not disapproved by the Bible, and that all are fanatics who cry out against his slaveholding as a heinous sin'. ${ }^{58}$ Warming to his theme, Shanks declared that as 'regards Slavery, Dr Hodge is the most dangerous man in America or in the world', 'the very essence of diabolical subtlety'. ${ }^{59}$

III.

The end of the Civil War allowed Presbyterians to focus again on the things that united them. William Gibson saw the cessation of hostilities as clearing the way for American Presbyterians to lead the advance of Christ's kingdom in a now-purified United States so 'that it might lay the glories of its youthful strength, the conquests of its manly prime, and the fruits of its world-wide commerce at Immanuel's feet, and help to carry the tidings of His salvation to the uttermost ends of the earth' ${ }^{60}$ G.H. Stuart attended the annual meeting of the Irish General Assembly in June 1866 and was encouraged to deliver an impromptu address on the work of the United States Christian Commission and the results of the Civil War. Stuart noted 'the many rebukes the Irish Church had given to the Presbyterian Churches who were connected with slavery' and suggested that deputations between both countries ought to be exchanged within the year. ${ }^{61}$ The General Assembly’s Committee in Correspondence with Foreign Churches agreed because such connections would 'tend to advance the interests of evangelical truth, and to promote national harmony and brotherly love'. The Assembly

\footnotetext{
55 S. M. Dill, The American conflict: a lecture (Belfast, 1863), p. 16.

${ }^{56}$ Isaac Nelson, The American War in relation to slavery. A lecture delivered to the Presbyterian Young Men's Society, Donegall Street. Belfast, 24th November, 1863 (Belfast, 1863).

${ }^{57}$ Life of Stuart, p. 29; for Stuart's attitude to slavery, pp 58-65. G. H. Shanks, Freedom and slavery: an explanation of the principles and issues involved in the American conflict; and the duty of the people of Britain in relation to that momentous struggle (Belfast, 1863), p. 12.

${ }^{58}$ Ibid., pp 44, 49.

${ }^{59}$ Ibid., p. 51.

${ }^{60}$ William Gibson, 'Events of the year' in Evangelical Witness and Presbyterian Review, iv (1865), p. 310.

${ }^{61}$ Life of Stuart, p. 195.
} 
rejoiced in 'the termination of the bloody struggle on American soil' and gave 'thanks to God, that the result of the conflict has been the abolition of slavery throughout the United States'. ${ }^{62}$

An important aspect of the renewed relationship was, once again, religious revival. One of the outcomes of 1859 was how the concept of revival was redefined more generally in the North Atlantic world from a sudden outbreak of religious fervour to increasingly planned and organised revival events. ${ }^{63}$ These were often led by professional revivalist preachers, the most famous of which was the American, Dwight L. Moody who was usually accompanied by the soloist, Ira D. Sankey. This new revivalism attracted middle-class churchgoers who were increasingly worried about intellectual developments antagonistic to Christianity as well as social and economic problems caused by industrialisation and urbanisation. Protestants in industrialised north-east Ulster shared these concerns and Moody was invited in 1874 to hold a mission after a very successful evangelistic campaign in Scotland. ${ }^{64}$ The mission was a remarkable success because the respectable and less anarchic quality of this well-organised revival appealed greatly to middle-class Presbyterians. An account of Moody's 1874 campaign in Britain and Ireland was produced in New York by G.H. Stuart and John Hall, a distant cousin of Stuart and a recent Irish Presbyterian immigrant to the United States. Hall was born in County Armagh in 1829 and had been a missionary in the west of Ireland before becoming the minister of First Armagh congregation in 1852 and Mary’s Abbey, Dublin, in 1858. In September 1867 he accepted a call to Fifth Avenue Presbyterian Church in New York and through his pastoral work and popular preaching made it the largest protestant congregation in the city. ${ }^{65}$ Hall and Stuart included a series of lengthy descriptions of Moody’s campaigns by Irish Presbyterians who all stressed the spiritual reality of the movement, the unity it created amongst evangelicals, and its respectable character. The Revd W.B. Kirkpatrick of Dublin noted, 'There are none of those doubtful physical accompaniments which characterized the awakening of 1859. There is no other excitement than that which is produced by the truth of God, brought home to the hearts of a listening multitude of awakening sinners.' 66

Crusades led by American revivalists became a common occurrence in late nineteenth-century Ulster, including return visits by Moody and Sankey in 1883 and $1892 .{ }^{67}$ Generally speaking, this

\footnotetext{
${ }^{62}$ MGA, iii (1866), p. 672.

${ }^{63}$ Bebbington, Dominance of evangelicalism, pp 99-102; Janice Holmes, Religious Revivals in Britain and Ireland 1859-1905 (Dublin, 2000).

${ }^{64}$ Joseph Thompson, 'The influence of D.L. Moody on Irish Presbyterianism’ in Patton (ed.), Ebb and flow, pp 119-40.

65 T. C. Hall, John Hall: pastor and preacher. A biography by his son (London, [1901]).

${ }^{66}$ John Hall and G. H. Stuart, The American evangelists, D.L. Moody and Ira D. Sankey, in Great

Britain and Ireland (New York, 1875), p. 249.

${ }^{67}$ The following paragraph draws upon A.R. Holmes, 'Revivalism and fundamentalism in Ulster: W.P. Nicholson in context', in D.W. Bebbington and David Ceri Jones (eds), Evangelicalism and fundamentalism: the experience of the United Kingdom during the twentieth century (Oxford, 2013), pp 256-62.
} 
revivalism was largely controlled and respectable, but it also encouraged a popular evangelical subculture that was emotional, flexible in its forms, separatist in the lifestyle it demanded of its adherents, pessimistic about the trend of world affairs, and which saw a connection between the prosperity of Ulster, the Union, and protestant religion. These themes were prominent in the personal experience of W.P. Nicholson who had been born - and 'born again' - in Ulster, but who had made a name for himself as a travelling evangelist in Scotland, Australia, and the United States. In 1914 he was ordained an evangelist by the Presbyterian Church in the United States and was subsequently employed by the Bible Institute of Los Angeles, a prominent fundamentalist institution. As discussed below, Nicholson's brand of populist revivalism would become increasingly popular amongst Ulster evangelicals in the twentieth century.

Before the revivals of the early 1920s, middle-class Presbyterians in Ireland and the United States continued to define revival in moderate terms. A good example of this was James McCosh who in 1868 left his position in Belfast to become the president of the College of New Jersey and would be responsible for its transformation into modern-day Princeton University. McCosh did much to encourage ‘vital religion' amongst his students in New Jersey, but he gained greater prominence as a significant figure in the intellectual world of transatlantic Protestantism and a prominent reconciler of evolutionary science and evangelicalism. ${ }^{68}$ On his departure from Belfast, the Irish General Assembly hoped 'that his labours in the land of his adoption may be instrumental in advancing the cause of true religion, and in strengthening the bonds of fellowship and communion that should ever unite the members of the body of Christ on both sides of the Atlantic'. ${ }^{69}$ Indeed, McCosh's career illustrates the importance of intellectual and theological connections across the North Atlantic. Closely connected with the College of New Jersey was Princeton Theological Seminary, founded in 1812 and one of the foremost theological colleges in the protestant world by the 1850 s. $^{70}$ Between 1812 and 1932, over 350 students from Ireland studied at the seminary, but arguably more important was the influence it had on the formation and character of theological education in Ireland. ${ }^{71}$ The Presbyterian College in Belfast was opened in 1853 and was inspired in part by the American seminary. William Gibson was a key figure in the enterprise and his son James had been a student at Princeton on the recommendation of Nicholas Murray, a trustee of the seminary. ${ }^{72}$ Writing in 1862, James Gibson described it as 'the headquarters of Presbyterianism in the world' and Charles Hodge as 'the first Presbyterian divine of his

\footnotetext{
${ }^{68}$ J. D. Hoeveler, James McCosh and the Scottish intellectual tradition from Glasgow to Princeton
} (Princeton, 1981); D. N. Livingstone, ‘James McCosh and the Scottish Intellectual Tradition’ in D. N. Livingstone and Alvin Jackson (eds), Queen's thinkers: essays on the intellectual heritage of a university (Belfast, 2008), pp 19-30.

${ }^{69}$ MGA, iii (1868), p. 998.

${ }^{70}$ J.H. Moorhead, Princeton Seminary in American religion and culture (Grand Rapids, MI, 2012).

${ }^{71}$ Peter Wallace, 'Irish students at Princeton Seminary: an example of the Ulster-American connection' in Livingstone and Wells, Ulster-American religion, pp 145-54.

${ }^{72}$ Prime, Memoirs of Murray, p. 406. 
day'. ${ }^{73}$ Charles Hodge’s grandfather was an Irish Presbyterian who emigrated to Pennsylvania from Ulster in the early eighteenth century. He was appointed a professor at Princeton Seminary in 1822 and became arguably the most influential protestant theologian in North America in the nineteenth century through teaching generations of students, his editorship of The Biblical Repertory and Princeton Review, and his many and varied publications. ${ }^{74}$

The Belfast college became known as a ‘citadel of Calvinism' under one of Hodge’s former students, Robert Watts, professor of systematic theology from 1866 to $1895 .{ }^{75}$ Though he had been born in County Down in 1820, he left in the 1840s with his recently-widowed mother for the United States and attended Lafayette College and Washington College before enrolling in Princeton Seminary. Watts was ordained in Philadelphia in 1853 and established a new congregation in the city through his missionary efforts in 1856. By chance he was appointed minister of Lower Gloucester Street congregation in Dublin in 1863 and three years later joined the faculty of the Presbyterian College. In 1862 Watts was a delegate of the Old School General Assembly to the Irish Assembly and during his speech noted that the Irish church was the mother of American Presbyterianism, a fact that had 'been twice proclaimed through the highest human authority in our Church - the Princeton Review' ${ }^{76}$ This periodical certainly was the mouthpiece of Calvinist evangelicalism in the North Atlantic world and in the late 1870s and early 1880s, two professors at the Presbyterian Magee College, Derry - Thomas Croskery and Thomas Witherow - were corresponding editors of it's successor, the Presbyterian Review. Watts himself was instrumental in shaping the theological outlook of a generation of Presbyterian ministers after the model of his former teacher and became 'a theologian of the distinctly Princeton type and school'. ${ }^{77}$ Watts stated that Hodge was 'the greatest of modern theologians' and his three-volume Systematic Theology (1872-3) 'viewed as an exhibition and defence of the Economy of Redemption ... is without a peer in the whole history of theological exposition' ${ }^{78}$

If a commitment to religious revival and Calvinist theology reflected the positive aspect of the Presbyterian vision, the negative was expressed in traditional anti-Catholicism. Reflecting on his firsthand experience of the bewildering variety of religious groups in the United States, the Revd William Magill of Cork noted the mortifying influence of 'the Roman Irish' who 'massed in their million strength by their priesthood, and actuated and possessed by their hereditary hatred to the rights of conscience, and the glories of Protestantism, are beginning to deal blows on some of the foundations of the commonwealth, and are a standing menace to its religious freedom and educational institutions’. ${ }^{79}$

\footnotetext{
${ }^{73}$ James Gibson, 'Princeton Theological Seminary’ in Evangelical Witness and Presbyterian Review, i (1862), pp 59-60.

${ }^{74}$ P. C. Gutjahr, Charles Hodge: guardian of American orthodoxy (New York, 2011).

${ }^{75}$ Robert Allen, The Presbyterian College Belfast 1853-1953 (Belfast, 1954), pp 161-88.

${ }^{76}$ Banner of Ulster, 12 July 1862.

77 James Heron, 'The death of the Rev. Prof. Watts, D.D. LL.D.’ in Witness, 2 Aug. 1895.

${ }^{78}$ Robert Watts, 'The Death of Dr Hodge’ in Witness, 5 July 1878.

${ }^{79}$ William Magill, 'A peep at America - V' in Evangelical Witness and Presbyterian Review, x (1871), p. 122.
} 
As noted previously, anti-Catholicism was a powerful force that united protestants throughout the North Atlantic world. The shared concern about the impact of post-Famine Catholic emigration from Ireland was exacerbated by the increasing 'Romanisation' of global Catholicism, the promulgation of papal infallibility at the Vatican Council, and the so-called 'Romeward trend' within the Church of England. A desire for united action against this threat and others found institutional expression in 1877 with the formation the Alliance of the Reformed Churches holding the Presbyterian System (later the World Alliance of Reformed Churches). The leading intellectual of the movement was James McCosh and Irish Presbyterians were amongst the first to suggest the formation of such an organisation. ${ }^{80}$ The advantages of such a union were obvious to the Irish Assembly as it would demonstrate 'that the Presbyterians constitute one of the largest denominations of Protestants in the world; that they have proved of all others most loyal to everything that was pure, vital, and Biblical in the Reformation of the sixteenth century; and that in whatever part of the world they exist they have been the true bulwark of Protestantism'. Presbyterian unity, vitality, and moral strength fitted them to be at the forefront of 'resisting Rationalism on the one side and Romanism on the other' ${ }^{81}$ The first three meetings of the alliance were held in Edinburgh (1877), Philadelphia (1880), and Belfast (1884).

In Ireland, these general trends were intensified through the overwhelming opposition of Ulster protestants in general to Irish Home Rule, which they believed was essentially 'Rome Rule' ${ }^{82}$ In response to these developments, many Presbyterians on both sides of the Atlantic built upon the themes they had been developing since the 1820s to further emphasise a Scotch-Irish and Ulster-Scots identity. This process involved a positive articulation of the contribution of Presbyterians to the modern world as well as a critique of the corrupt character and influence of the Irish Catholic diaspora. These themes were expressed with force by Thomas Croskery, an Irish Presbyterian minister, prominent Ulster Liberal, exponent of Presbyterian evangelicalism, and professor at Magee College Derry from 1875 to 1886. ${ }^{83}$ Croskery was a prolific contributor to the periodical literature of the day and by doing so helped shape attitudes to British government policy in Ireland and the religious condition of the Irish population at home and overseas. An article entitled 'The Irish Abroad' in the 1868 edition of the Edinburgh Review stated that the Presbyterian Scotch-Irish had made America great. The migration of Presbyterians in the eighteenth century was contrasted with the modern emigration of the 'Celtic Irish', who consisted 'mostly of hungry and ignorant peasants, driven by the scourge of famine from their own shores - flying desolation rather than seeking a home - without resources, without character, and without any wholesome influence to restrain and regulate them' ${ }^{84}$ In a hostile review of J.F. Maguire’s

\footnotetext{
${ }^{80}$ J. D. Hoeveler, 'Evangelical ecumenism: James McCosh and the intellectual origins of the World Alliance of Reformed Churches’ in Journal of Presbyterian History, lv (Spring 1977), pp 36-56. ${ }^{81}$ MGA, iv (1874), p. 700.

${ }^{82}$ David Hempton and Myrtle Hill, Evangelical protestantism in Ulster society 1740-1890 (London, 1992), pp 161-87.

${ }^{83}$ William Irwin, 'Our own worthies. The Rev. Thomas Croskery, D.D.' in Presbyterian Churchman (Dec. 1886), pp 313-20.

${ }^{84}$ Thomas Croskery, 'The Irish abroad’ in Edinburgh Review, cxxvii (1868), pp 502-37, 506.
} 
The Irish in America (1867), he described the work as 'an undiscriminating panegyric upon Irishmen of every class in America, except the hated Scotch-Irish of the North'. ${ }^{85}$ Maguire had 'studiously ignored the evils of the Celtic emigration and the injuries it has inflicted upon American society', commended the attacks on the public school system by priests, adopted 'the side of the archbishops and bishops with all the spirit of an Ultramontane, lauding and approving their repeated assaults upon the liberties of the Romish laity', and wrote 'as if America is never destined to reach the highest summit of earthly power and glory till it has bowed its haughty head to the Roman obedience'. ${ }^{86}$

Notwithstanding these concerns, Croskery identified three reasons to be hopeful: the degraded character of American Catholicism and its easy assimilation into American Protestantism; the strength of American institutions, especially the public school system; and the vigour of American Protestantism, which was in essence biblical, Presbyterian, and Calvinist. ${ }^{87}$ This misleading analysis, especially his overstated characterisation of American Protestantism, was informed by Croskery’s denominational background and advocacy of a distinctive Scots-Irish / Ulster-Scots contribution to preRevolutionary America. In a booklet written for delegates at the third Presbyterian Alliance meeting in Belfast in 1884, Croskery claimed, 'It was owing to this emigration that the basis of American society is Presbyterian and not Anglican. We have always regarded with a peculiar interest that strong, orthodox, expansive Presbyterianism, which derives its origin from our humble forefathers - a Presbyterianism instinct with evangelical vigour, and free from Anglo-Catholic reactions, which now establishes a sort of equipoise between the Popery and the Protestantism of the world.' ${ }^{88}$ In 1885 Croskery offered an extended discussion of American Presbyterianism in which he challenged Charles Briggs' characterisation of it as English in origin and broad in theology. ${ }^{89}$ Croskery argued instead that the key features of American Presbyterianism could all be traced back to Scottish and Irish settlers love of doctrine, spiritual life, and revival, its voluntary character and salutary impact on social discipline, commitment to education, and struggle for political independence. As Presbyterianism had made America great, so Croskery hoped that his work would 'inspire the hope that Presbyterianism is destined to a yet wider expansion in the most rapidly progressive of modern nations'. ${ }^{90}$

Brigg's attempt to demonstrate the English origins of American Presbyterianism did not convince most of his coreligionists who continued to look instead to Scotland and Ireland. At the time of the Jubilee commemoration in 1890 of the formation of the Irish General Assembly, the indebtedness of American Presbyterians to their Irish forefathers was duly acknowledged. In a letter to

85 Thomas Croskery, 'The Irish in America' in Evangelical Witness and Presbyterian Review, vii (1868), p. 85.

${ }^{86}$ Ibid., pp 86-7.

${ }^{87}$ Thomas Croskery, 'Romanism in the United States' in British and Foreign Evangelical Review, xxv (1877), pp 669-82.

${ }^{88}$ Thomas Croskery, Irish Presbyterianism (Belfast, 1884), p. 41.

${ }^{89}$ C. A. Briggs, American Presbyterianism: its origin and early history (New York, 1885).

90 Thomas Croskery, ‘American Presbyterianism’ in British and Foreign Evangelical Review, xxxiv (1885), pp 401-26, 425. 
the Irish church, it was noted that 'the Scotch-Irish, as we call them,' formed 'a most important element in the numbers and strength of our Church at the present time. Our common interest in a heroic contest for the truth by our forefathers on your soil, our common heritage of a sound faith, our common aim in the extension of the Redeemer's Kingdom we regard as reasons for intimacy with your body, and as bonds strengthening our fellowship in the Lord. ${ }^{91}$ John Hall attended the jubilee celebrations in Belfast and delivered an address on 'Irish Presbyterianism in other lands' in which he made much of the impact of the Scotch-Irish. Hall claimed 'no people have made so substantial a contribution to the free institutions of the United States as these people that came from the province of Ulster'. The wholehearted commitment of eighteenth-century Presbyterian emigrants to 'the sacredness of personal rights and the claims of conscience' placed them above the Puritans and Episcopalians in terms of influencing the principles of the Constitution because they 'were enabled to embody and comprehend in that organic life the notions of civil and religious liberty that had been taught them, and so to establish a government over the people and by the people'. ${ }^{92}$ In terms of 'loyalty to the truth, for integrity of character, for consistency of living, for Sabbath observance, for energy, for adherence to Christian principle', there was no group in the United States more reliable 'than the people who have come from this province of Ulster, and bear the name, the honoured name, of Irish Presbyterians'.93

A distinctive Scotch-Irish identity in the United States was expressed through a series of publications as well as the formation in 1889 of the Scotch-Irish Society of America, an attempt to assert the distinctness of the group from Americans of Anglo-Saxon and Celtic origin. ${ }^{94}$ Though it was dominated by protestants from urban areas in the northern states, the Society did attempt to be nonsectarian and adopted a neutral stance on Irish Home Rule. ${ }^{95}$ Many American protestants who traced their origins back to Ulster were now to be found in Baptist and Methodist churches, though the term 'Presbyterian' was most frequently heard at the meetings of the Society. It is significant that the most strident advocacy of a Presbyterian Scots-Irish identity came from Ulster-born members of the Society, especially John Hall and George Macloskie. Macloskie was born in County Londonderry in 1834 and educated at both Queen's College, Belfast and the Presbyterian College before becoming the minister of Ballygoney in $1861 .{ }^{96}$ Owing to the influence of James McCosh, Macloskie in 1875 was appointed

${ }^{91}$ MGA, vii (1890), p. 1031.

92 John Hall, 'Irish Presbyterianism in other lands' in Jubilee of the General Assembly of the Presbyterian Church in Ireland, Belfast, July, 1890 (Belfast, 1890), pp 157, 158.

93 Ibid., p. 160.

${ }^{94}$ For example, C. A. Hanna, The Scotch-Irish, or the Scot in North Britain, North Ireland, and North America (2 vols, London and New York, 1902); C. K. Bolton, Scotch Irish pioneers in Ulster and America (Boston, 1910); H. J. Ford, The Scotch-Irish in America (Princeton, 1915).

${ }^{95}$ Matthew McKee, ““A peculiar and royal race”: creating a Scotch-Irish identity. 1889-1901’ in Patrick Fitzgerald and Steve Ickringill (eds), Atlantic crossroads: historical connections between Scotland, Ulster and North America (Newtownards, 2001), pp 67-83.

${ }^{96}$ Fasti of the General Assembly of the Presbyterian Church in Ireland 1840-1910, ed. J. M. Barkley (3 vols, Belfast 1986-7), i, 56. 
professor of biology at Princeton and, like his patron, attempted to reconcile evolutionary science with evangelical religion. ${ }^{97}$

At the meeting of the Scotch-Irish Congress in Pittsburgh in 1890, there was a debate about whether a resolution ought to be passed that the society was 'not organized in antagonism to any class of the Irish or Scotch races', a reference primarily to Irish Catholic immigrants. Hall argued that it was needless to pass such a resolution as it would place the Society on the defensive, that the constitution already stated its non-sectarian character, and that Presbyterians were 'the best friends the Catholics ever had' in Ireland. Hall's arguments carried the day and the motion was laid on the table. ${ }^{98}$ It has been suggested that this episode demonstrates that the Society desired to rise above the divisiveness of Irish politics and that a broad and inclusive definition of Irishness survived in the South into the twentieth century and was sometimes associated with Irish nationalism. ${ }^{99}$ This was undoubtedly the view of some members of the Congress, but it is also clear that this was not the view taken by Hall and Macloskie who advocated the Liberal Unionist case against Irish Home Rule. At a meeting in Atlanta in 1892, Hall declared that he shared the unionism of Irish Presbyterians and that if the audience accepted the description of 'the prudence, the wisdom, the foresight, the sagacity, the integrity of my countrymen and the people of my race, the Scotch-Irish race ... then you must surely come to the conclusion that it is not without reason that this attitude of antagonism is taken to what is known commonly as the Home Rule policy’. ${ }^{100}$ Reflecting his professional interests, Macloskie talked in Atlanta about 'the struggle for existence' of the Scotch-Irish and how Makemie's success 'exemplifies the survival of the fittest'. Macloskie sought to offer a moderate description of Presbyterian opposition to Home Rule and was eager to discuss Presbyterian support for liberty and equality through the disestablishment of the Church of Ireland and land reform.

... they are not bigots, they are not fanatics, they are not men who want an ascendancy of their own party, but they are men who are afraid of an ascendancy rising up in the place of the old one that after long struggles they have gotten rid of, and now they are wanting to preserve this principle of fairness and freedom, and I say it is a struggle for existence, it is not a struggle for domination, it is not a struggle to rob anybody of his rights. ${ }^{101}$

There was no direct equivalent in Ireland of the Scotch-Irish Society, though the formation of the Presbyterian Historical Society of Ireland in 1906 provided a forum for the articulation of a

\footnotetext{
${ }^{97}$ D. N. Livingstone, Darwin's forgotten defenders: the encounter between evangelical theology and evolutionary thought (Grand Rapids, 1987), pp 92-6.

98 The Scotch-Irish in America. Proceedings and addresses of the second congress at Pittsburgh, Pennsylvania May 29 to June 1, 1890 (Cincinnati, 1890), pp 59-60.

${ }^{99}$ D.T. Glesson, 'Smaller differences: “Scotch-Irish” and "Real Irish” in the nineteenth-century American South’ in New Hibernian Review, x, no. 1 (Summer 2006), pp 87-9.

100 John Hall, 'The Ireland of to-day' in The Scotch-Irish in America. Proceedings and addresses of the fourth congress, at Atlanta, GA., April 28 to May 1, 1892 (Nashville, 1892), p. 156.

${ }^{101}$ George Macloskie, 'The evolution of the Scotch-Irish' in The Scotch-Irish ... fourth congress, at Atlanta, pp 221, 222.
} 
Presbyterian Ulster Scots identity. It was also an important channel for diffusing a usable past that could be employed for contemporary needs, most obviously during the Third Home Rule crisis. ${ }^{102}$ The contribution of Presbyterians to the New World was articulated in March 1912 by Whitelaw Reid, the United States Ambassador to the United Kingdom, who delivered a lecture to the Historical Society in Belfast on 'The Ulster Scot'. For Reid, the Declaration of Independence summed up 'the conclusions to which for years the Scots and Ulster Scots had been leading', while they were also 'responsible for the separation, for the War of Independence, for the conquest of the Mississippi Valley, for the Constitution, for the administration of the Government, for the anti-slavery movement, and for the Civil War'. ${ }^{103}$ In response to Reid's lecture, the Presbyterian newspaper, the Witness, noted that on the evidence of the material prosperity of Ulster and the United States, as well as Canada and other parts of the Empire, the 'Ulster Scot is in the ascendant today'. ${ }^{104}$ The dominance of Presbyterian themes was clearly expressed throughout the following year, especially the signing of the Ulster Covenant in September. ${ }^{105}$ In the midst of the crisis in 1913, the Society organised the three-hundredth anniversary of the arrival of the first Scottish minister in Ireland. It was 'thought proper' to mark the arrival as it saw 'the beginnings of a form of worship that has had a profound influence on the character of a race which has played a large part in the Old and New Worlds, particularly as pioneers of civilisation, and as framers of constitutions'. ${ }^{106}$

The forging of unionist unity from the disparate materials of Irish Protestantism did lead to the waning of a distinctive Presbyterian interpretation of politics after the Third Home Rule crisis. ${ }^{107}$ The importance of Presbyterian symbols should not obscure that development and nor should we ignore the continued importance of religious themes and connections across the North Atlantic. During the

${ }^{102}$ A.R. Holmes, 'Irish Presbyterian commemorations of their Scottish past, c. 1830 to 1914' in James McConnel and Frank Ferguson (eds), Across the water: Ireland and Scotland in the nineteenth century (Dublin, 2009), pp 59-60; 'Presbyterian religion, historiography, and Ulster Scots identity, c. 1800 to 1914’ in Historical Journal, lii (2009), pp 634-40.

${ }^{103}$ Whitelaw Reid, The Scot in America and the Ulster Scot. Being the substance of addresses before the Edinburgh Philosophical Institution, 1st November 1911, and the Presbyterian Historical Society, Belfast, 28th March 1912 (London, 1912), pp 39, 66.

104 'The Ulster Scot' in Witness, 29 March 1912.

105 Graham Walker, A history of the Ulster Unionist party: protest, pragmatism and pessimism (Manchester, 2004), pp 32-6.

${ }^{106}$ Education in Ulster: narrative of early attempts towards the establishment of a Presbyterian university. Reports of the Presbyterian Historical Society of Ireland, 1912-1914 (Belfast, 1914), p. 5. 107 The following discussion draws upon Holmes, 'Revivalism and fundamentalism in Ulster' and 'Biblical authority and the impact of Higher Criticism in Irish Presbyterianism, c. 1850-1930' in Church History, lxxv (2006), esp. pp 359-73. For a different reading see D. W. Miller, 'Ulster evangelicalism and American culture wars' and 'Searching for a New World: the background and baggage of Scots-Irish immigrant', in Hofstra (ed.), Ulster to America, 1-23. 
twentieth century, however, 'Presbyterian’ identity for religious conservatives was overshadowed by trans-national and trans-denominational evangelicalism. The most important development of the early years of the century was the expansion of religious revivalism and the emergence of protestant fundamentalism during the 1920s. Fundamentalists were militant evangelicals who were angry about modernising trends within church and state. Initially so-called 'modernism' was successfully opposed in the United States by theological conservatives such as Charles Hodge, but it came to constitute an important movement within mainstream Protestantism. Modernism did not develop to the same degree within Irish Presbyterianism, yet modern theological views were articulated and were opposed from within the revivalist tradition that grew out of 1859. This provided the background for the outbreak of revival amongst protestants in Northern Ireland between 1921 and 1923, which was led by the characteristically transatlantic personality, W.P. Nicholson. Though he received widespread support in the early 1920s, Nicholson was later accused of being a 'militant fundamentalist' whose influence brought about the heresy trial in 1926-7 of J. E. Davey, a professor in the Presbyterian College, Belfast. Despite the links between these developments and the rise of Ian Paisley in the 1950s, Nicholson’s brand of revivalism and personal religion has attracted many more evangelicals than the religious separatism of Paisley. What Nicholson represents is how a distinctive Presbyterian version of North Atlantic Protestantism was undermined by non-denominational evangelical religion, the religious equivalent of the submergence of a Presbyterian politics into broad-church unionism. The irony is that the transatlantic evangelical world Irish Presbyterians had an important role in creating and maintaining in the previous two centuries would contribute to undermining their distinctive denominational character in the late twentieth century. 